V. 13 N. 3

SET-DEZ 2017

ISSN 2317-6172

Recebido: 16.05 .2016

Aprovado: 05.05.2017

DOI: http://dx.doi.org/10.1590/2317-6172201732

1 Escola de Direito de São Paulo da Fundação Getulio Vargas São Paulo - SP - Brasil

\section{O direito contratual comparado em nova perspectiva: revisitando as diferenças entre os sistemas romano-germânico e de common law}

A NEW PERSPECTIVE ON COMPARATIVE CONTRACT LAW: REVISITING THE DIFFERENCES BETWEEN CIVIL AND COMMON LAW SYSTEMS

Mariana Pargendler ${ }^{1}$

\section{Resumo}

Este artigo busca oferecer uma nova interpretação de certas distinções clássicas entre o direito dos contratos romano-germânico e anglo-saxônico. Desta análise surge um padrão claro, mas até então negligenciado. 0 sistema de civil law impõe mais limitações ao conteúdo das obrigações contratuais, valorizando o papel da boa-fé como standard de conduta obrigatório e impondo um maior número de cláusulas de natureza cogente. 0 sistema de common law, em contrapartida, estabelece limitações mais contundentes aos remédios disponíveis em caso de inadimplemento contratual, invalidando cláusulas penais, qualificando a execução específica como remédio excepcional e concedendo mais generosamente um "novo começo" (fresh start) na insolvência. Não obstante, os diferentes papéis do Estado na fiscalização das cláusulas do contrato e na imposição de consequências jurídicas para o inadimplemento são, em larga medida, substitutos funcionais, o que torna os resultados concretamente obtidos em ambos os sistemas mais próximos do que se esperaria ao se examinar os diferentes institutos de forma isolada.

\section{Palavras-chave}

Direito contratual; direito comparado; tradição romano-germânica; common law; método funcional.

\begin{abstract}
This article seeks to offer a novel interpretation of certain classical differences between the civil and the common law of contracts. This analysis reveals a clear, but so far neglected, pattern. The civil law imposes greater limitations on the scope of contractual obligations, by recognizing a stronger duty of good faith and imposing more mandatory terms. The common law system, by contrast, more forcefully constrains the remedies available for breach of contract, by invalidating penalty clauses, qualifying specific performance as an exceptional remedy, and more generously granting a "fresh start" in bankruptcy. Nevertheless, the different roles of the State in policing the terms of the contract and imposing remedies for non-performance are, to some extent, functional substitutes. This means that practical outcomes in both systems are closer than one would anticipate by focusing on individual rules and institutions in isolation.
\end{abstract}

\section{Keywords}

Contract law; comparative law; civil law; common law; functional method. 


\section{INTRODUÇÃO}

Como o direito dos contratos difere de um país para outro? Esta questão tem atraído grande interesse acadêmico e prático ao longo do tempo. Durante a maior parte da história do direito comparado como disciplina, o direito dos contratos foi o seu principal objeto de estudo (FARNSWORTH, 2006, p. 900). No entanto, a vasta maioria das obras existentes sobre o direito contratual comparado apresenta natureza descritiva, concentrando-se no relato de diferenças e semelhanças entre as normas jurídicas de vários países (a título exemplificativo: VON MEHREN, 1976). Mesmo as melhores análises "funcionais", exemplificadas pela obra seminal de Zweigert e Kötz (1998), cuidam precipuamente da dogmática jurídica, destinando relativamente pouca atenção ao ambiente econômico e político correspondente.

O resultado é que, embora se tenham notícias sobre como o direito dos contratos difere de um país para outro, ainda se sabe comparativamente pouco sobre as razões e as implicações dessas divergências. As diferenças observadas nas várias dimensões do direito dos contratos são geralmente tratadas de forma isolada e arbitrária, como se fossem produto de acontecimentos fortuitos na história do direito (FARNSWORTH, 2006, p. 901; MATTEI, 1995, p. 427 e 433). Percebe-se, assim, a falta de narrativas mais amplas sobre o modo como as distinções existentes relacionam-se entre si, bem como com outros aspectos dos sistemas jurídico, econômico e político. Tal lacuna no direito contratual comparado contrasta fortemente com o estado da arte em outras áreas do estudo comparativo - como a governança corporativa e o direito constitucional -, campos nos quais os vários regimes jurídicos vêm sendo examinados de forma conjunta $\mathrm{e}$ em termos funcionais, levando em conta as estruturas econômicas e políticas subjacentes (ARMOUR; ENRIQUES et al., 2017; MILHAUPT; PISTOR, 2008; GINSBURG; DIXON, 2013).

Existem, obviamente, exceções a essa tendência. Por exemplo, o trabalho de Katharina Pistor sobre as "normas jurídicas fundamentais" que constituem as diferentes variedades de capitalismo abarca não apenas o direito societário (como é de praxe na literatura), mas também o papel da boa-fé no direito contratual (PISTOR, 2005). Da mesma forma, o estudo de Aditi Bagchi sobre as estratégias regulatórias do direito contratual apresenta foco relativamente estreito: nele se explica a preferência por normas dispositivas nos Estados Unidos e por normas cogentes na Europa em função de certas "características macroeconômicas da economia política" (BAGCHI, 2014, p. 687). A investigação mais abrangente sobre a interação entre o direito contratual e a economia política circundante é de John Reitz (2007), a qual, porém, aborda apenas algumas das diferenças centrais entre o direito contratual das diferentes tradições jurídicas, sem resolver as aparentes contradições entre elas.

Já este artigo adota uma visão mais ampla, examinando de maneira coordenada algumas das distinções doutrinárias centrais - e persistentes - no direito contratual de sistemas 
romano-germânico e de common law. ${ }^{1} \mathrm{O}$ foco recairá sobre as distinções que têm atraído maior atenção de acadêmicos e operadores do direito sobre o tema. São elas: ${ }^{2}$

(i) o papel mais forte da boa-fé contratual na tradição romano-germânica;

(ii) o maior número de normas cogentes na tradição romano-germânica;

(iii) a maior exigibilidade das cláusulas penais na tradição romano-germânica;

(iv) a maior disponibilidade da execução específica na tradição romano-germânica; e

(v) a maior disponibilidade da extinção contratual por meio de um "novo começo" (fresh start) no direito anglo-saxônico da insolvência. ${ }^{3}$

À primeira vista, é difícil vislumbrar qualquer lógica nessas distinções. A presença (i) de obrigações mais amplas decorrentes da boa-fé contratual e (ii) de mais normas cogentes nos países de civil law pode levar a concluir que os sistemas anglo-saxônicos proporcionam um papel na liberdade contratual que os sistemas romano-germânicos - conclusão esta que, aliás, representa um estereótipo corriqueiro na prática jurídica e empresarial (BANCO MUNDIAL, 2015). Tal visão, porém, suscita dificuldades. Se o common law é efetivamente comprometido com a santidade do contrato, por que ele (iii) não confere exigibilidade às cláusulas penais de caráter punitivo livremente acordadas pelas partes, (iv) se recusa a reconhecer direito subjetivo à execução específica (mesmo que as partes tenham expressamente pactuado este mecanismo) e (v) extingue mais facilmente as obrigações contratuais em processos de insolvência?

1 Para uma elaboração mais detalhada e em língua inglesa dos argumentos aqui desenvolvidos, cf. Pargendler (2017a).

2 Os itens (i) a (iv) estão certamente entre os mais correntes entre comparatistas e advogados. Outros tópicos populares na literatura comparatista são: a formação dos contratos (inclusive o papel comparado da contrapartida no common law e da causa no civil law), a interpretação contratual, o erro, o ajuste de cláusulas contratuais diante de mudanças exógenas, a responsabilidade pré-contratual e o papel da culpa no direito dos contratos. Com exceção da formação dos contratos (e da distinção entre causa e consideration) e do papel da culpa no direito dos contratos, esses temas são tratados no item 1.1.3 infra.

3 No presente artigo, segue-se a tradição do direito comparado ao utilizar o termo insolvência em sentido amplo, de modo a abranger não somente as hipóteses em que "as dívidas excedam a importância dos bens do devedor" (Código Civil, art. 955), mas também as hipóteses de falta de liquidez e impontualidade no cumprimento das obrigações que autorizam os regimes e procedimentos jurídicos próprios para empresas ou indivíduos em crise financeira. 
Esta análise sugere que essas diferenças podem ser, em larga medida, reconciliadas mediante a compreensão do diferente papel do Estado em ambas as tradições jurídicas. Nos sistemas de civil law, o Estado tende a desempenhar um papel mais robusto em todos os aspectos. Por um lado, o Estado, por meio do Poder Legislativo e do Poder Judiciário, vai mais longe na provisão e na fiscalização das cláusulas substantivas do contrato para assegurar a sua conformidade com valores e objetivos sociais mais amplos. Por outro lado, depois que o contrato passa neste "teste", o Estado também se dispõe a punir o inadimplemento com consequências mais severas, permitindo a exigibilidade de cláusulas penais de caráter abertamente punitivo, concedendo a execução específica do contrato e dificultando a extinção das obrigações contratuais em processos de insolvência.

Os sistemas de common law, em contrapartida, adotam a abordagem oposta: os órgãos legislativos e os tribunais são menos propensos a interferir nas cláusulas do contrato, bem como a amparar a parte lesada pelo inadimplemento. Na conceitualização de Ian Macneil sobre as duas dimensões da liberdade contratual, o common law favorece apenas uma versão estreita desta liberdade, no sentido de ausência de restrições (freedom from restraint). No entanto, a tradição romano-germânica consagra com maior força a outra faceta da liberdade contratual, o "poder contratual" (power of contract), que consiste na capacidade de assegurar sanções jurídicas para o incumprimento (MACNEIL, 1961, p. 495).

Esse padrão, por sua vez, permite duas interpretações distintas, mas complementares. A primeira é que as características do direito contratual nos sistemas anglo-saxônico e romano-germânico espelham o papel mais amplo do Estado nessas diferentes tradições: os arranjos do direito e da execução dos contratos são mais liberais nos sistemas de common law e mais intervencionistas nos sistemas de civil law. Essa visão coaduna-se com as conclusões da ampla literatura sobre o papel do Estado nas diversas tradições jurídicas (HAYEK, 1973; DAMAŠKA, 1986; LA PORTA; LOPEZ-DE-SILANES; SHLEIFER, 2008). Ao mesmo tempo, contudo, ela se revela parcialmente conflitante com a noção prevalecente de que o common law atribui necessariamente mais valor - e oferece maior proteção - aos arranjos contratuais privados. Com efeito, quando se leva em conta os remédios mais modestos para o inadimplemento do contrato, o apoio do Estado aos contratos privados nos países anglo-saxônicos mostra-se muito mais frágil. Em outras palavras, o common law não necessariamente protege melhor os contratos privados, mas sim favorece a ordenação privada, inclusive com respeito aos mecanismos para a exigibilidade de obrigações contratuais.

A segunda interpretação é que os diferentes papéis do Estado (i) no controle das cláusulas do contrato e (ii) na imposição de remédios jurídicos em caso de descumprimento são, em larga medida, substitutos funcionais. Isso significa que os resultados finais em ambos os sistemas são mais próximos do que se esperaria ao se examinar diferentes normas e institutos isoladamente. Em particular, a análise oferecida aqui salienta como o controle substantivo de cláusulas contratuais, de um lado, e a fresh start na insolvência, de outro, podem servir como mecanismos alternativos para alocar os riscos contratuais e mitigar os efeitos 
de compromissos contratuais excessivamente gravosos - uma relação crucial que foi largamente ignorada pela literatura existente. Na medida em que a substituição funcional ocorre, as diferenças aparentes no papel do Estado não produzirão necessariamente resultados econômicos divergentes, o que serve de advertência com relação a esforços de convergência em facetas distintas do direito contratual sem a devida consideração de dimensões complementares.

A análise será apresentada neste artigo da seguinte forma: o item 1 examina as principais diferenças entre as tradições romano-germânica e anglo-saxônica relativamente ao direito contratual e ao cumprimento forçado (enforcement) de contratos, bem como o respectivo grau de envolvimento estatal; o item 2 analisa em que medida as diferenças observadas implicam divergências práticas ou substituição funcional; e a Conclusão traz uma reflexão sobre o futuro do direito contratual comparado.

\section{i Análise comparativa}

Antes de proceder à análise das principais áreas de divergência entre o direito dos contratos romano-germânico e anglo-saxônico, cabem algumas advertências. Em primeiro lugar, é importante reconhecer que os padrões descritos aqui surgiram, em sua maioria, como produto de contingências históricas em um processo não teleológico. Eles não foram imutáveis ao longo da história, nem decorrem de uma engenharia social consciente modulada por distintas concepções sobre a função do Estado. Em segundo lugar, existe um amplo consenso no sentido de que os sistemas romano-germânico e anglo-saxônico vêm convergindo gradualmente com o tempo, reduzindo-se as diferenças que eram indiscutivelmente mais nítidas no passado (SPAMANN, 2009, p. 1813-1815; contra LEGRAND, 1996). Essa afirmação é particularmente frequente acerca do direito dos contratos, uma área em que a fertilização cruzada e os empréstimos de institutos romanísticos pelo common law foram mais evidentes (NICHOLAS, 1973, p. 946). Em terceiro lugar, verificam-se notáveis complexidades e divergências no interior de cada uma das tradições jurídicas. A descrição que se segue deve ser lida como uma aproximação estilizada, e não como um retrato preciso do regime prevalecente em algum país específico.

Não obstante, é correto dizer que certas diferenças relativas entre as tradições jurídicas persistem (ainda que menos pronunciadas do que no passado) e continuam a merecer a atenção de comparatistas e operadores do direito. As diferenças relativas são, afinal, o objeto por excelência do direito comparado (WHITMAN, 2004, p. 1151). Para fins expositivos, essas diferenças relativas serão provisoriamente agrupadas em duas categorias de institutos jurídicos que (i) ditam as cláusulas substantivas do contrato, isto é, os principais direitos e deveres das partes contratantes; e (ii) especificam remédios contratuais, isto é, as consequências jurídicas disponíveis para a parte lesada em caso de inadimplemento. 


\section{I DETERMinAÇÃo DO CONTEÚDO DA OBRIGAÇÃo CONTRATUAL}

\section{I.I.I A BOA-FÉ CONTRATUAL}

De todos os tópicos do direito contratual comparado, talvez nenhum tenha atraído tanto interesse em tempos recentes quanto a boa-fé contratual. Quando Alan Farnsworth descreveu sua experiência como representante dos Estados Unidos nos esforços de harmonização que levaram à Convenção de Viena sobre Contratos de Compra e Venda Internacional de Mercadorias (CISG, sigla em inglês) e aos princípios da Unidroit, a boa-fé encabeçava sua lista de distinções cruciais entre o direito dos contratos anglo-saxônico e romano-germânico (FARNSWORTH, 1996, p. 234). Reinhard Zimmermann e Simon Whittaker dedicaram um volume inteiro a uma investigação funcional (baseada em padrões factuais hipotéticos) acerca do alcance da boa-fé contratual na Europa - uma questão na qual, pelo menos em princípio, parece haver uma separação bastante clara entre civil law e common law (ZIMMERMANN; WHITTAKER, 2000).

Dado que a boa-fé sabidamente cumpre múltiplas funções no direito dos contratos (assim como em outras áreas do direito), cuida-se aqui precipuamente de seu papel na formatação do significado e do alcance do adimplemento contratual. ${ }^{4}$ Especificamente, a questão central é saber se, e em que medida, a boa-fé atua como fonte de deveres contratuais implícitos de cooperação e colaboração além daqueles expressamente previstos pelas partes. Em termos gerais, o consenso é de que os países da tradição romano-germânica contemplam atualmente uma aplicação mais expansiva da boa-fé contratual (MACKAAY, 2011).

Evidentemente, a distinção quanto ao alcance da boa-fé nas diferentes tradições é somente de grau. Nem todos os sistemas de direito continental adotam-na com o mesmo entusiasmo. A Alemanha - onde a boa-fé atua como "carvalho judicial que sombreia a relação contratual das partes privadas" - foi pioneira na valorização do instituto (EBKE; STEINHAUER, 1995, p. 171). Nesse espectro, alguns países, como o Brasil, acolheram-no com ainda maior fervor (MARTINS-COSTA, 2015), enquanto outros, como a França, seguiram mais relutantes (ZIMMERMANN; WHITTAKER, 2000).

No entanto, a boa-fé contratual não é estranha ao mundo anglo-saxônico. O Código Comercial Uniforme (Uniform Commercial Code - UCC) dos Estados Unidos - que harmonizou a legislação estadual a respeito da compra e venda de mercadorias - prevê especificamente a aplicação do dever de boa-fé no cumprimento e execução de todo contrato (UCC,

4 A boa-fé objetiva no direito romano-germânico é suficientemente ampla para incluir várias outras funções, como impor um dever de cuidado nas tratativas pré-contratuais e desencorajar o comportamento contraditório que viola as expectativas legítimas da outra parte (tal como expressa no brocardo non venire contra factum proprium), função esta que no direito anglo-saxônico é geralmente exercida pela doutrina do estoppel. Sobre as diferentes funções da boa-fé objetiva no direito brasileiro, cf., por todos, Martins-Costa (2005). 
$\S 1$-304). A adoção da boa-fé pelo UCC não foi acidental, e sim fruto da influência alemã por meio do seu idealizador germanófilo, Karl Llewellyn. Ademais, a boa-fé contratual é relevante também fora do contexto do UCC, pois numerosas decisões judiciais norte-americanas recorrem ao dever de boa-fé do common law para preencher lacunas dos contratos e impor deveres de conduta além daqueles expressamente enunciados pelas partes (PARGENDLER, 2007). Não obstante, os tribunais dos Estados Unidos utilizam a boa-fé para impor deveres contratuais com menos frequência e fervor do que seus equivalentes no civil law.

O direito inglês foi historicamente ainda mais relutante - verdadeiramente hostil ao princípio, "[recusando-se] terminantemente a reconhecer qualquer dever de boa-fé" (FARNSWORTH, 1996, p. 235). Por certo, como exemplar raro de país anglo-saxônico na União Europeia antes do "Brexit”, foi difícil para a Inglaterra resistir à atração gravitacional da boa-fé nos esforços de harmonização em matéria contratual. Ainda assim, a convergência plena permanecia ilusória, tendo Gunther Teubner observado que a boa-fé na Inglaterra serviria mais como "irritante jurídico” do que como "transplante jurídico” (TEUBNER, 1998). Os esforços para divulgar a Inglaterra como o melhor país para a solução de controvérsias em assuntos comerciais continuam a ressaltar "a ausência de um dever geral de boa-fé" no direito inglês como um de seus principais argumentos de propaganda (LAW SOCIETY OF ENGLAND AND WALES, 2007, p. 5).

Até hoje subsiste o debate sobre qual abordagem relativa à boa-fé é preferível sob perspectiva normativa - se aquela mais expansiva, característica do civil law, ou mais restritiva, encontrada no common law. A teoria econômica postula que os contratos no mundo real são necessariamente incompletos: a combinação de custos de transação com racionalidade limitada impede as partes de especificarem contingências ótimas para cada estado de coisas possível. Nesse contexto, os tribunais poderiam promover a eficiência usando a boa-fé para oferecer às partes as cláusulas que "elas teriam negociado" se não fossem os custos de transação e sua capacidade de previsão limitada (EASTERBROOK; FISCHEL, 1993; PARGENDLER, 2007).

Resta claro, no entanto, que um papel mais atuante da boa-fé - seja preenchendo lacunas no contrato, seja alterando cláusulas contratuais explícitas - implica um papel mais forte do Estado na adjudicação contratual. Sobretudo nesta última função, a boa-fé substitui a tomada de decisão privada por uma tomada de decisão coletiva necessariamente inspirada por valores sociais - quer isso seja desejável da perspectiva das partes, quer não. É essa característica que, para Katharina Pistor, faz da boa-fé contratual um dos fundamentos jurídicos das economias de mercado coordenadas - fundamento este que, a seu ver, ajuda a explicar a correlação observada entre os sistemas de civil law e as economias de mercado coordenadas (PISTOR, 2005).

I. i. 2 Normas cogentes e normas dispositivas “aderentes”

Além da boa-fé e de outros princípios que permitem aos juízes revisar ou extinguir os 
contratos ex post, outra característica distintiva do direito dos contratos na tradição romanogermânica é a presença de numerosas normas legais sobre os vários "tipos" de contratos (compra e venda, permuta, comodato, agência, seguro etc.). Na verdade, a classificação em contratos "típicos" (que são disciplinados por lei, geralmente pelo próprio Código Civil) e contratos “atípicos” (que não o são) é basilar no direito contratual romano-germânico (PARGENDLER, 2016). Enquanto no common law os contratos são percebidos como fenômeno unitário, o conceito de tipos de contrato é crucial no civil law (PARGENDLER, 2016).

Embora a tradição romano-germânica reconheça a existência de contratos atípicos, essa categorização permanece relevante. Isso porque, se um contrato é típico - e, como o nome sugere, a maioria dos contratos correntemente celebrados é típica -, as normas cogentes e dispositivas previstas no Código ou na legislação esparsa a ele se aplicam. A presença de tais normas, por sua vez, é significativa, por diferentes razões. Algumas dessas normas são notoriamente cogentes e, portanto, representam claramente uma limitação imposta pelo Estado à liberdade contratual. Outras vezes (como, por exemplo, no caso do art. 623 do Código Civil brasileiro), a legislação é omissa em relação ao caráter dispositivo ou cogente da norma, suscitando acirrada controvérsia doutrinária.

Tradicionalmente, a maioria das normas legais tem natureza dispositiva (jus dispositivum), aplicando-se somente na ausência de acordo das partes, que podem livremente estipular em sentido contrário. Contudo, até as normas dispositivas podem ser "aderentes" (sticky) na prática e, nessa condição, restringir a liberdade contratual (BEN-SHAHAR; POTTOW, 2006). Existem pelo menos três conjuntos de razões que explicam a dificuldade de se afastar, na prática, as normas legais dispositivas. Em primeiro lugar, os tribunais em toda parte frequentemente concluem que as normas dispositivas incorporam algum tipo de noção superior de justiça e, por isso, aplicam-nas contrariamente aos termos do acordo, transformando-as efetivamente em normas cogentes (SCHWARTZ, 2003, p. 596). Em segundo lugar, o legislador pode intencionalmente impedir que as partes se furtem às normas dispositivas mediante a imposição de procedimentos custosos para evitá-las (AYRES, 2012, p. 2045). Em terceiro lugar, para além das preferências judiciais e das estratégias regulatórias, as conclusões da economia comportamental mostram que os vieses cognitivos das próprias partes, como os efeitos de "ancoragem" e "dotação", dissuadem o desvio das normas dispositivas quando elas existem (KAHAN; KLAUSNER, 1996; KOROBKIN, 1998a; KOROBKIN, 1998 b).

Os méritos e as desvantagens da provisão, pelo Estado, de normas dispositivas e cogentes também permanecem controvertidos, a depender da visão que se tenha da capacidade do Estado de sanar as falhas do mercado e antecipar as necessidades das partes. De um lado, as normas dispositivas podem ser mecanismos poderosos para reduzir custos de transação. A presença de normas legais dispositivas que são tanto abundantes quanto equilibradas pode ajudar a explicar por que as partes contratantes nos países romanistas conseguem redigir contratos mais curtos (PARGENDLER, 2016). De outro lado, quando mal concebidas, as normas dispositivas e, especialmente, as cogentes impedem a adoção de cláusulas contratuais eficientes. 
De qualquer modo, é nítida a tendência de maior intervenção (ou, se preferir, assistência) do Estado com respeito às cláusulas contratuais no civil law do que no common law. Os advogados anglo-saxônicos costumam se sentir desconfortáveis com a abordagem continental, "talvez por causa de sua antipatia para com a ordenação hierárquica de burocracias legiferantes centralizadas" (KÖTZ, 2012, p. 15). No direito anglo-saxônico, as partes habitualmente compensam a falta de cláusulas fornecidas pelo Estado por meio da oferta privada de cláusulas padronizadas (boilerplate), o que oferece vantagens comparáveis em termos de externalidades de rede e economia de custos de transação (KAHAN; KLAUSNER, 1997; DAVIS, 2006). Ainda é uma questão aberta saber se as soluções públicas ou privadas são superiores nesse contexto, o que suscita discordância até mesmo entre as mentes mais razoáveis.

\section{I . I . 3 Outros institutos}

O papel mais intervencionista do Estado no civil law também ilumina outras diferenças fundamentais no direito dos contratos. Tomemos, por exemplo, a difícil questão de saber se mudanças exógenas nas circunstâncias após a formação do contrato devem afetar as obrigações nele previstas. Ao passo que os tribunais alemães inicialmente recorreram à cláusula geral de boa-fé do art. 242 do BGB para revisar cláusulas contratuais diante da hiperinflação na década de 1920, outros países da tradição romano-germânica usaram teorias (ou cláusulas gerais) diversas para lidar com problemas semelhantes, como a imprévision na França (embora tradicionalmente limitada a contratos com o Estado), a eccessiva onerosità sopravvenuta na Itália e a onerosidade excessiva no Brasil. Remédios judiciais para alterações imprevistas nas circunstâncias também existem no common law, geralmente no âmbito dos conceitos de frustration of purpose e impracticability.

O sentido geral da divergência entre direito anglo-saxônico e romano-germânico é semelhante ao observado em outras áreas: os juízes romano-germânicos mostram-se mais propensos que os anglo-saxônicos a reescrever ou extinguir os contratos ex post quando esse resultado não foi expressamente contemplado pelas partes. Na descrição de Hans Baade, sobre as diferenças na aplicação da frustration of purpose e na cláusula rebus sic stantibus, "a norma de common law é, ou parece ser, estreita demais para acomodar o mundo empresarial na era atual de catástrofe econômica aleatória”, ao passo que "a norma de civil law do século XX, desenvolvida principalmente na Alemanha, por outro lado, parece perigosamente aberta à manipulação subjetiva" (BAADE, 1983, p. 510).

Nesse sentido, é ilustrativa a decisão judicial em Aluminum Company of America v. Essex Group (499 F. Supp. 53 (W. D. Pa. 1980), que fornece exemplo célebre de como um juiz norte-americano pode estar disposto a reescrever cláusulas contratuais diante da alteração de circunstâncias. Ao constatar que o índice de inflação adotado no contrato gerou um ganho inesperado para uma das partes (e ao impor um índice alternativo, o que sequer havia sido pedido), o juiz Teitelbaum citou especificamente o direito de vários países de matriz romanista (como Alemanha, Brasil e Argentina), que aceitam a revisão judicial dos contratos. O 
juiz notou que, embora "a época da lex mercatoria tenha passado, e nosso sistema jurídico difira do deles", os Estados Unidos "não têm o monopólio da sabedoria e podem muito bem aproveitar a experiência e o aprendizado de outras nações" (p. 78 da decisão). Surpreendente no contexto norte-americano, esse grau de intervenção judicial em cláusulas contratuais atraiu críticas consideráveis (MACAULAY, 1985, p. 475). Embora os comentadores tenham gasto muita tinta no exame dessa decisão, a sentença controversa do caso Alcoa nunca foi aplicada, e o caso teve impacto mínimo em outras decisões (MACAULAY, 1985, p. 475; HALPERN, 1987 , p. 1127). Na mesma linha, os tribunais norte-americanos também vêm se mostrando relutantes em aplicar os institutos da impracticability e da frustration of purpose (DAWSON, 1984, p. 2; GOLDBERG, 2012, p. 266).

Além de reescrever ou não as cláusulas do contrato para adequá-las às novas circunstâncias, os tribunais também podem adotar uma abordagem mais ou menos intervencionista na interpretação contratual. Os juízes desempenham um papel mais forte quando estão mais dispostos a (i) considerar provas extrínsecas relativas à fase de tratativas e (ii) depreender obrigações contratuais além daquelas expressas no acordo escrito, a fim de fazer jus à verdadeira intenção das partes. Por outro lado, desempenham um papel mais modesto quando se recusam a olhar para além da moldura do contrato escrito e a reescrever o instrumento para refletir melhor os desejos presumidos das partes. Também nessa área, o civil law consagra um maior papel ao Estado, enquanto o common law aproxima-se mais de uma abordagem laissez-faire da interpretação contratual (VOGENAUER, 2007; LEONHARD, 2009, p. 2; MAGNUS, 2011, p. 181-182). De fato, a maior omissão - que caracteriza os tribunais anglo-saxônicos, especialmente na Inglaterra (ocasionalmente permitindo até mesmo resultados implausíveis) -, gera fortes incentivos para que as partes especifiquem elas mesmas suas obrigações.

A medida pela qual os países estão dispostos a revisar ou anular cláusulas contratuais especialmente em relações contratuais assimétricas - também varia segundo as mesmas linhas. O direito alemão é famoso por impor um controle rígido às cláusulas contratuais padronizadas, mesmo em contratos empresariais (DANNEMANN, 2011, p. 76). Na França, os juízes possuem amplos poderes para negar validade a cláusulas abusivas em contratos de consumo, abordagem esta que foi recentemente estendida pela reforma do Code a todos os contratos de adesão em relações paritárias (SMITS; CALOMME, 2016, p. 7). No Reino Unido, o Unfair Contract Terms Act de 1977 também regula as cláusulas padronizadas, mas se mostra menos rígido do que o seu correspondente alemão (DANNEMANN, 2011, p. 75). Nos Estados Unidos, os juízes podem recorrer ao instituto da unconscionability para deixar de aplicar cláusulas contratuais injustas, mas raramente o fazem (DIMATTEO; RICH, 2006, p. 115; FLEMING, 2014, p. 386).

Por fim, vale notar que o direito contratual romano-germânico contempla um papel estatal mais robusto não apenas na provisão e interpretação das cláusulas contratuais, mas também na imposição de obrigações às partes antes que elas concluam um contrato. Outra distinção 
famosa na literatura comparatista diz respeito ao alcance da responsabilidade pré-contratual (COLOMBO, 1983, p. 341). Embora as diferentes etiquetas doutrinárias ocultem um grau significativo de substituição funcional (KESSLER; FINE, 1964), os países romanistas são mais favoráveis às hipóteses de responsabilidade civil na fase de tratativas (COLOMBO, 1983, p. 369; FARNSWORTH, 1987, p. 239; CARDENAS, 2013, p. 945).

\section{I.2 CONSEQUÊNCIAS JURÍdiCAS DO INADIMPLEMENTO}

No que tange ao conteúdo da obrigação contratual, a comparação entre o direito romano-germânico e o anglo-saxônico revela um padrão razoavelmente claro, segundo o qual o Estado, no civil law, demonstra maior propensão a intervir no conteúdo das cláusulas contratuais, complementando ou mesmo suplantando a escolha das partes. Esta seção mostrará que, curiosamente, o mesmo padrão de maior envolvimento do Estado no civil law é visível com respeito aos remédios cabíveis em caso de inadimplemento do contrato. Como discutido mais detalhadamente a seguir, depois que um contrato passa pelo crivo mais rigoroso sobre o conteúdo de suas cláusulas, o Estado também é mais agressivo em sua execução, concedendo, paralelamente, remédios contratuais mais fortes para o caso de inadimplemento e restringindo a disponibilidade de reabilitação na insolvência. Se um controle mais leniente das cláusulas contratuais poderia sugerir que o common law respeita mais a liberdade contratual, seu tratamento das consequências do inadimplemento refuta generalizações superficiais.

\section{I . 2 . I EXECUÇÃO ESPECÍfICA}

Outra área central de divergência entre civil law e common law diz respeito à possibilidade de se recorrer à execução específica das obrigações contratuais. Como regra, os países romanistas consideram a execução específica como o principal remédio em caso de inadimplemento contratual. Em contrapartida, a principal consequência do inadimplemento contratual no common law é a obrigação de pagar perdas e danos (SCHLESINGER et al., 1998, p. 740). Nas célebres palavras de Oliver Wendell Holmes, “o dever de cumprir um contrato na common law equivale à previsão de que você deve pagar perdas e danos se não o cumprir - e nada mais" (HOLMES, 1897, p. 462). A execução específica, um remédio oriundo da equity, permanece excepcional no direito contratual anglo-saxônico, disponível somente quando a indenização por perdas e danos não é “adequada”, e mesmo assim sujeita à discricionariedade do juiz (Restatement [Second] of Contracts, $§ \S 357$ e 359, 1981; Uniform Commercial Code $\S 2-716[1])$.

Tal como em outras áreas, os estudiosos têm questionado o alcance e a relevância dessa divergência. Primeiro, a disponibilidade da execução específica não é uniforme nos sistemas de origem romano-germânica, mas varia de país para país, sujeitando-se a diferentes exceções (TREITEL, 1976; LANDO; ROSE, 2004). Segundo, a execução específica pode não ser usada com frequência significativa na prática romano-germânica, mesmo quando está formalmente disponível "nos livros" (LANDO; ROSE, 2004, p. 486; ZWEIGERT; KÖTZ, 
1998, p. 161). Terceiro, os tribunais anglo-saxônicos têm sido cada vez mais liberais ao deferir a execução específica, sugerindo convergência maior entre ambas as tradições (LAYCOCK, 1991). Não obstante, diferenças conceituais e práticas persistem (KLASS, 2010, p. 212).

A hesitação do common law em conceder a execução específica dos contratos tem suscitado intensas controvérsias. Por um lado, a primeira geração dos estudos de Direito e Economia formulou a famosa teoria do "inadimplemento eficiente" (efficient breach) para justificar a norma anglo-saxônica (POSNER, 1973). Segundo essa teoria, ao permitir o inadimplemento do contrato exigindo o pagamento de perdas e danos à parte lesada, o sistema anglo-saxônico efetivamente possibilita a violação de obrigações contratuais. Tal resultado, porém, pode ser eficiente se, por meio do pagamento de indenização, a parte inocente for colocada na mesma posição em que estaria se o contrato tivesse sido cumprido. Apesar da respeitabilidade alcançada pela teoria do inadimplemento eficiente, uma vasta literatura contestou sua validade, argumentando que a execução específica pode conduzir a resultados mais eficientes e mais compatíveis com as intuições de cunho moral (ULEN, 1984; FRIEDMANN, 1989; BROOKS, 2006; SHIFFRIN, 2009).

Enquanto o debate teórico continua aberto, a prática comercial revela que as partes contratantes frequentemente elegem a execução específica com relação a certos tipos de obrigações contratuais. Um estudo empírico de Theodore Eisenberg e Geoffrey Miller constatou que mais de 55\% dos contratos de fusão ou incorporação e 45\% dos contratos de compra e venda de ativos nos Estados Unidos continham disposições que previam a possibilidade de execução específica em caso de inadimplemento (EISENBERG; MILLER, 2015, p. 32). Contudo, em uma clara restrição à liberdade contratual, as partes contratantes nos países anglo-saxônicos não têm garantia de que sua opção pela execução específica prevalecerá em juízo. As cláusulas de cumprimento específico costumam influenciar, mas não determinar, a decisão judicial, que permanece discricionária.

A par da discussão sobre qual seria o remédio jurídico mais eficiente como regra dispositiva, é intrigante a relutância do common law em reconhecer direito subjetivo à execução específica quando as partes expressamente optaram por este remédio, sobretudo à luz do alegado prestígio que a autonomia das partes goza nesta tradição. Uma dificuldade adicional é que, ao contrário da pressuposição central na teoria do inadimplemento eficiente, as indenizações por perdas e danos na vida real raramente compensam plenamente o dano sofrido pela parte inocente (EISENBERG, 2005; SHAVELL, 2006, p. 451). Na verdade, quando se leva em conta as regras aplicáveis para a quantificação dos danos, o contraste com o tratamento dos remédios contratuais na tradição romano-germânica torna-se ainda mais marcante. Não apenas a execução específica é a regra, mas as hipóteses de cabimento de perdas e danos e a quantificação da indenização, pelo menos em teoria, parecem ser mais generosas nos países de civil law (SCALISE, 2007, p. 743-744 e 763) - embora se alegue que seja mais difícil, na prática, obter indenização por lucros cessantes na tradição romano-germânica em razão de dificuldades probatórias (GOTANDA, 2006). 
A compreensão do forte papel do Estado associado à execução específica ajuda a esclarecer a questão. A opção pela execução específica é muito mais coercitiva e opressiva do que a indenização por perdas e danos. Na tradição anglo-saxônica, em particular, o descumprimento de ordens judiciais para o cumprimento específico é punível como desacato ao tribunal, conduzindo a multas, prisão ou ambos (KLASS, 2010, p. 211). Assim concebida, a execução específica é "muito intrusiva e altamente coercitiva” (EISENBERG, 2005, p. 1049). Alan Farnsworth observa que, além de fatores relacionados à dependência da trajetória histórica (path dependence), "uma base mais racional [da relutância dos tribunais dos Estados Unidos em conceder execução específica] pode ser encontrada na severidade das sanções disponíveis" para tal fim (FARNSWORTH, 1999, p. 769).

De fato, embora as diferenças entre os mecanismos usados para implementar a execução específica nos sistemas continentais e anglo-saxônicos sejam relevantes, elas têm sido negligenciadas. Os países de common law costumam carecer de um mecanismo similar às astreintes francesas para incentivar a execução específica (KLASS, 2010, p. 211). A existência desses mecanismos mais brandos para garantir o cumprimento contratual poderia ajudar a explicar a preferência comparativa de que goza a execução específica nos países de direito romano-germânico. Porém, é provável que esse não seja o único fator determinante. Isso porque o common law também se opõe a remédios contratuais fortes mesmo quando nenhuma sanção criminal está envolvida, como veremos no seu tratamento das penalty clauses, a seguir abordado.

\section{2.2 Cláusulas penais}

A relutância do common law em fornecer remédios robustos para o caso de inadimplemento contratual não se limita à execução específica que, como vimos, implica forte coerção estatal por meio do direito penal. A mesma tendência restritiva existe quando se trata da estipulação, pelas próprias partes, de quantia a ser paga a título de punição pelo inadimplemento. Em um contraste marcante com o civil law (HATZIS, 2003, p. 381), o common law nega exigibilidade às chamadas penalty clauses, que são disposições contratuais que visam punir (e, portanto, dissuadir) o inadimplemento contratual estipulando o pagamento de uma soma que excede a quantia que presumivelmente seria necessária para compensar a parte lesada pelo incumprimento.

$\mathrm{O}$ direito dos contratos anglo-saxônico traça uma distinção essencial entre liquidated damages clauses, que são válidas, e penalty clauses, que não são. Embora haja distinções sutis entre o direito de diferentes jurisdições, a qualificação de uma cláusula como estipulação válida de pré-liquidação da indenização (liquidated damages) geralmente depende de saber se a quantia em questão "é razoável à luz da perda prevista ou efetiva provocada pelo inadimplemento e da dificuldade de prova da perda" ${ }^{5}$ Em contrapartida, "[uma] cláusula que fixa liquidated damages

5 Restatement (Second) of Contracts § 356(1) (1981). Ver também UCC § 2-718 (1): "Damages for breach by either party may be liquidated in the agreement but only at an amount which is reasonable in the light 
irrazoavelmente elevados é inexigível, por questões de política pública, porque constitui uma penalidade". 6

Essa proscrição generalizada às cláusulas punitivas do inadimplemento não encontra paralelo na tradição romanista. Na verdade, os Códigos Civis típicos expressamente reconhecem e regulam as cláusulas penais (Código Civil francês, art. 1.226 et seq.; BGB § 339 et seq.; Código Civil brasileiro, art. 408 et seq.). Isso não significa que a liberdade contratual com respeito às cláusulas penais seja absoluta no civil law. A maioria dos países hoje prevê explicitamente (e crescentemente) várias limitações, inclusive o poder do juiz de reduzir cláusulas que são manifestamente excessivas. Não obstante, o simples fato de uma determinada soma exceder uma estimativa razoável dos danos decorrentes do inadimplemento é, por si só, insuficiente para assegurar a revisão judicial da cláusula penal - seu caráter punitivo foi, e continua a ser, parte do conceito. Ao contrário, aponta-se que, mesmo após a eventual redução de uma cláusula exorbitante, a quantia devida há de exceder os danos efetivamente sofridos (SCHLESINGER et al., 1998, p. 746).

$\mathrm{Na}$ qualidade de exceção ao princípio da liberdade contratual, a rejeição das penalty clauses no common law é controversa, para dizer o mínimo. Tal como a ausência de execução específica, a teoria do inadimplemento eficiente também serviu para explicar a hostilidade do direito anglo-saxônico para com as penalty clauses (POSNER, 1973). Contudo, são numerosas as críticas a esse regime, possivelmente ainda mais contundentes do que aquelas que concernem à execução específica. Diversos autores têm justificado a eficiência das penalidades contratuais, tendo em vista que elas: oferecem plena compensação aos contratantes com valorações idiossincráticas (GOETZ; SCOTT, 1977); permitem aos novos participantes do mercado assinalar sua capacidade de cumprir com as obrigações contratualmente assumidas (POSNER, 1977, p. 93-94); dissuadem formas de incumprimento que são difíceis de detectar (EDLIN; HERMALIN, 2000); possibilitam às partes negociar opções implícitas que atuam como garantias (SCOTT; TRIANTIS, 2004; TRIANTIS, 2010, p. 657); e induzem níveis eficientes de investimento específico à relação (EDLIN; SCHWARTZ, 2003).

É curioso que os países mais intervencionistas tendam a apoiar remédios mais fortes para o caso de inadimplemento contratual. Os países socialistas - que, de regra, pouco valorizavam a liberdade contratual - não apenas reconheciam um direito inalienável à execução específica como principal remédio para o inadimplemento contratual, como também empregavam e exigiam cláusulas penais com fervor (GROSSFELD, 1963, p. 1331 e 1341; EÖRSI,

of the anticipated or actual harm caused by the breach, the difficulties of proof of loss, and the inconvenience or nonfeasibility of otherwise obtaining an adequate remedy. A term fixing unreasonably large liquidated damages is void as a penalty."

6 Restatement (Second) of Contracts $\S 356(2)$ (1981). 
1987, p. 153-154). De fato, as cláusulas penais eram cogentes no direito socialista, sendo invariavelmente pactuadas nos contratos entre empresas estatais (SCHLESINGER et al., 1998, p. 757).

Finalmente, é também notável que a resistência anglo-saxônica às cláusulas penais não se estenda às disposições que visam limitar a responsabilidade contratual - por exemplo, oferecendo o pagamento de uma soma inferior aos prejuízos efetivamente incorridos. Diferentemente das penalty clauses, o common law não impõe limitações gerais às cláusulas de limitação da responsabilidade (MATTEI, 1995, p. 433; EDLIN; SCHWARTZ, 2003, p. 35). No civil law, verifica-se o padrão oposto: a maioria dos países tende a sujeitar as cláusulas de limitação da responsabilidade a um escrutínio considerável, comparável ou maior ao aplicável às cláusulas penais. Nessa área também, o civil law parece favorecer remédios contratuais fortes, e o common law, fracos.

\section{I.2.3 Novo COMEÇO (FRESH START)}

Outra diferença sistemática quanto à execução contratual nas diversas tradições jurídicas concerne à facilidade com que as partes conseguem obter a extinção de dívidas, incluindo-se as decorrentes de obrigações contratuais, em caso de insolvência. Em contraste com a análise feita até aqui, agora mudamos o foco para institutos que formalmente pertencem ao direito da insolvência, e não dos contratos. Não há dúvida, porém, de que a possibilidade de reabilitação do falido afeta a perspectiva de execução contratual de modo fundamental. Embora raramente examinada, a interação entre o direito dos contratos e o direito da insolvência pode ser esclarecedora, como veremos adiante.

A nota central dessa distinção é que o common law tem, em geral, leis de insolvência mais clementes que o civil law (LOPES, 2003, p. 91). Especificamente, os países anglo-saxônicos são mais liberais ao reconhecer o direito a um "novo começo" (fresh start), no qual os indivíduos podem ter suas dívidas extintas após um período especificado (ZIEGEL, 2006, p. 300). Os processos de insolvência também parecem ser mais frequentes no mundo anglo-saxônico. Um estudo empírico de Stijn Claessens e Leora F. Klapper constatou que, após controlar os choques macroeconômicos e o nível de desenvolvimento financeiro, os pedidos de falência ou recuperação judicial são mais numerosos nos países de common law (CLAESSENS; KLAPPER, 2002). Embora um estudo mais recente tenha constatado que os pedidos de insolvência de consumidores aumentaram em toda parte entre 2002 e 2008 nos países examinados, com exceção dos Estados Unidos, o número de pedidos nos países de common law analisados (Estados Unidos, Inglaterra, Canadá e Austrália) ainda era consideravelmente mais alto que em países de matriz romanista, como Alemanha e França (LONDON ECONOMICS, 2012).

No mundo anglo-saxônico, os Estados Unidos destacam-se, de longe, como o país mais favorável aos devedores em várias dimensões (ARMOUR; ENRIQUES et al., 2017). O direito da insolvência norte-americano foi pioneiro em reconhecer o direito dos devedores à fresh 
start desde o final do século XIX (SKEEL, 2014, p. 1). Tornou-se célebre a formulação da Suprema Corte dos Estados Unidos no caso Local Loan Co. v. Hunt, segundo a qual uma das principais finalidades da bankruptcy law é conceder “ao devedor honesto mas desventurado, que entrega para liquidação a propriedade que lhe pertence no momento da falência (bankruptcy), uma nova oportunidade na vida e um espaço livre para o esforço futuro, desimpedido pela pressão e desestímulo da dívida preexistente” (292 U.S. 234, 244 [1934]).

A bankruptcy individual continuou, desde então, a desempenhar papel importante na vida econômica norte-americana. O número de processos judiciais cresceu drasticamente durante o século XX, especialmente após a Bankruptcy Law mais liberal de 1978, ultrapassando um milhão de pedidos por ano em meados dos anos 1990 (WHITE, 1998, p. 685). Em 2005, 1,6 milhão de consumidores nos Estados Unidos - o que equivale a um em cada 71 domicílios - estavam insolventes (LAWLESS; WARREN, 2006). Enquanto alguns comentadores criticavam os incentivos aos pedidos oportunistas por parte até mesmo de devedores de alta renda (WHITE, 1998, p. 686), outros louvavam o papel do direito falimentar dos Estados Unidos por propiciar uma rede de segurança diante de um Estado do bem-estar fraco (LAWLESS; WARREN, 2006). É curioso que o direito da insolvência constitui verdadeira plataforma para a doutrina progressista nos Estados Unidos (SKEEL, 2000). Em contrapartida, juristas progressistas nos países de civil law tendem a dedicar-se ao exame judicial de cláusulas contratuais e demais esforços legislativos voltados para a proteção do consumidor.

Enquanto as leis estadunidenses são excepcionalmente protetivas dos devedores e liberais na concessão da fresh start, o conceito também está presente em outros países anglo-saxônicos (GROSSMAN, 1996, p. 1). Não obstante, a combinação de estigma, obstáculos procedimentais e discricionariedade judicial tornou significativamente mais difícil para os indivíduos obter a reabilitação na Inglaterra, no Canadá e na Austrália do que nos Estados Unidos (ZIEGEL, 2006, p. 300). Mesmo assim, quando considerados em um espectro, os países de common law geralmente oferecem um regime de insolvência muito mais liberal e protetivo do devedor que os de civil law (ZIEGEL, 2006, p. 300).

É sabido que os países de direito romano-germânico adotaram uma abordagem mais punitiva nos processos de insolvência, cujo principal objetivo é fornecer uma ferramenta de execução para os credores, não um auxílio para os devedores (HULS, 1992, p. 133). Pelo menos historicamente, a maioria dos países de tradição romano-germânica sequer reconhecia o conceito de falência individual, e nenhum deles adotava a ideia de reabilitação (ZIEGEL, 2006, p. 300; NIEMI-KIESILÄINEN, 1999, p. 479). Se a obrigação contratual passasse no teste das diversas formas de controle estatal das cláusulas contratuais, a consequência geral seria a responsabilidade pelas dívidas dela decorrente pela vida toda (HULS, 1992, p. 133). Costumava-se justificar a ausência de fresh start no mundo romano-germânico com base justamente no ideal pacta sunt servanda (ZIEGEL, 2006, p. 304). Paradoxalmente, o mesmo princípio foi gradualmente enfraquecido para permitir uma intervenção estatal crescente no conteúdo das cláusulas contratuais. 
No entanto, reconhecer essas diferenças gerais entre as tradições jurídicas não significa negar que haja uma variação considerável no interior dessas tradições, bem como uma mudança ao longo do tempo. Esse campo passou por uma convergência significativa em anos recentes, de forma talvez ainda mais acentuada do que em outras áreas. Por um lado, uma série de países de civil law, abertamente inspirados pelo direito dos Estados Unidos, adotaram a ideia de fresh start nas últimas décadas (HULS, 2012, p. 497; RAMSAY, 2007, p. 250). A Europa, em particular, conheceu "uma verdadeira enxurrada de novas leis de insolvência", começando com a Dinamarca (1984), seguida pela Escócia (1985), França (1989) e Alemanha (1999), entre outros países, com vistas a conceder um tratamento mais generoso aos devedores (TABB, 2005, p. 765).

Por outro lado, a promulgação do Bankruptcy Abuse Prevention and Consumer Protection Act de 2005 (BAPCA), motivada por intensa pressão das empresas de cartão de crédito, dificultou sobremaneira a obtenção da fresh start pelos consumidores norte-americanos. A nova lei, entre outras coisas, impôs numerosos obstáculos procedimentais e condicionou a disponibilidade de reabilitação imediata no âmbito do Capítulo 7 do Bankruptcy Code a um "teste de meios" - uma complicada fórmula concebida para avaliar a capacidade dos consumidores de pagar suas dívidas; aqueles reprovados no teste ficam impedidos de pleitear um novo começo no âmbito do Capítulo 7 e devem ser redirecionados ao plano de pagamento parcial nos termos do Capítulo 13 do Bankruptcy Code. ${ }^{7}$ Porém, os pequenos empresários que têm sobretudo dívidas da empresa continuam isentos desse teste (WHITE, 2006). Como planejado, o BAPCA foi eficaz ao desestimular os processos de insolvência, embora não necessariamente eficiente de um ponto de vista social. Um estudo recente constatou que, uma década após a reforma, os pedidos de falência caíram para um milhão por ano, mas a insolvência persistente e as execuções de hipotecas aumentaram na mesma proporção (ALBANESI; NOSAL, 2015).

Contudo, não se verifica plena convergência em torno de uma política de fresh start. Conquanto os países europeus continentais tenham progressivamente adotado os conceitos de falência individual e reabilitação, as diferenças com relação ao modelo anglo-saxônico permanecem substanciais. A abordagem europeia costuma condicionar a reabilitação tanto a juízos morais quanto às origens da dívida e a um plano de pagamento compulsório plurianual (NIEMI-KIESILÄINEN, 1999, p. 475). De forma coerente com o foco em remédios contratuais mais fortes em outras áreas, a Europa continental geralmente rejeita a abordagem get out of jail free tradicionalmente associada ao direito norte-americano (KILBORN, 2003-2004, p. 281). As distinções são tantas que os estudiosos até criaram diferentes rótulos para descrever os diversos modelos utilizados. Na definição de Niemi-Kiesiläinen, as iniciativas de

7 Para uma descrição e avaliação crítica da reforma, ver Lawless e Warren (2006). 
reforma na Europa continental envolvem um “ajuste da dívida do consumidor”, contrastando-as ao modelo de "falência do consumidor" prevalecente no mundo anglo-saxônicos (NIEMIKIESILÄINEN, 1999, p. 476). Outros autores aludiram à existência de um "começo merecido" (earned start) na Europa, em contraste ao "novo começo" (fresh start) do direito norte-americano (REIFNER et al., 2003). ${ }^{8}$

De um modo geral, continua a ser verdade que os países de common law contemplam mais comumente uma abordagem mais liberal da insolvência que os de direito romano-germânico. A questão é, então, o que explica essa divergência? O direito inderrogável à fresh start colide com noções básicas de liberdade contratual. Porém, ao afetar a exigibilidade dos contratos - mas não propriamente a validade de suas cláusulas substantivas -, a fresh start pode ser concebida como uma limitação do poder do Estado de forçar coativamente o cumprimento das obrigações contratuais. Como observaram juristas norte-americanos, a "falência é a derradeira limitação à disposição do Estado de forçar seus cidadãos a pagar dívidas privadas" (SULLIVAN; WESTBROOK; WARREN, 1989, p. 4).

O surgimento da política de fresh start (e suas variantes) soa compatível com um papel menos intervencionista do Estado. Há muito que os autores enfatizam a conexão entre a desregulação dos mercados de crédito na Europa e a introdução da reabilitação do consumidor falido, tipicamente por governos conservadores (NIEMI-KIESILÄINEN, 1999, p. 502). Ao mesmo tempo em que proporciona auxílio aos devedores, o novo começo é, nas palavras de Nick Huls, "uma forma branda de intervenção; sua implementação exige relativamente pouca interferência do Estado” (HULS, 1992, p. 130).

\section{DivergênCIA EFETIVA OU SUBSTITUIÇÃo FUNCIONAL?}

Como na maioria das empreitadas comparativas, o enfoque em normas e institutos jurídicos de forma isolada pode levar a que se superestimem as diferenças reais entre os vários sistemas jurídicos. Um dos axiomas centrais do moderno direito comparado é justamente que os países chegam muitas vezes ao mesmo resultado recorrendo a formulações doutrinárias díspares (ZWEIGERT; KÖTZ, 1998, p. 36). Por exemplo, em tese, poder-se-ia esperar um certo grau de substituição funcional entre a disponibilidade da execução específica e a exigibilidade das cláusulas penais. Comparatistas de renome suscitaram justamente esta hipótese ao afirmar que "um sistema jurídico que descarta ou enfraquece excessivamente um dos dois mecanismos [penalidades ou cumprimento específico] tornar-se-á mais dependente do outro" (SCHLESINGER et al., 1998, p. 756-757). Contudo, não é isso que observamos:

8 Esse estudo, contudo, agrupa a Inglaterra e a Irlanda com os outros Estados membros, apesar de reconhecer que, ao admitir a reabilitação, esses regimes são historicamente mais próximos dos Estados Unidos que os da Europa continental. 
nas diferentes áreas aqui examinadas, o civil law reiteradamente exige um papel mais forte do Estado tanto no controle quanto na exigibilidade das cláusulas contratuais em comparação ao common law.

Isso posto, os distintos papéis do Estado no controle das cláusulas contratuais e no enforcement das obrigações contratuais podem atuar como substitutos funcionais. Em larga medida, pode-se dizer que o direito romano-germânico e o anglo-saxônico adotam estratégias diferentes para mitigar os efeitos de negócios excessivamente gravosos. Enquanto o civil law recorre mais à padronização legal e controle judicial das cláusulas contratuais para assegurar a justiça da troca, o common law limita os remédios disponíveis em caso de incumprimento. Ocorre que isso conduz muitas vezes, embora não sempre, aos mesmos resultados práticos por caminhos doutrinários bastante distintos.

Para ilustrar esse ponto, consideremos a célebre decisão de 1993 da Corte Constitucional alemã (Bundesverfassungsgericht) no caso Bürgschaft - um julgado que se tornou símbolo da disposição dos tribunais alemães de levar em conta os direitos constitucionais fundamentais na interpretação e execução de contratos privados. ${ }^{9}$ A decisão da Corte Constitucional cuidou da difícil questão relativa aos "efeitos horizontais dos direitos constitucionais" nas relações privadas (Drittwirkung der Grundrechte) - ou o que a doutrina constitucionalista norte-americana chama de problema da "ação de Estado" (State Action). Como ensina Mark Tushnet, não é coincidência que o tratamento dessa questão central no direito constitucional esteja ligado a diferentes concepções do papel do Estado, com as sociais-democracias revelando-se mais dispostas a reconhecer tais efeitos horizontais do que os países que adotam formas mais limitadas de governo (TUSHNET, 2003, p. 80).

Os fatos do caso envolviam uma filha de 21 anos que assinou um contrato para ser fiadora do seu pai, um empresário, como condição imposta pelo banco para estender o limite de crédito dele de DM 50.000 para 100.000. Ao solicitar a garantia, o funcionário do banco teria dito a ela: "Você pode só assinar aqui, por favor? Isso não vai criar nenhuma obrigação importante para você; preciso disso para a documentação" (CHEREDNYCHENKO, 2004). Posteriormente o pai deixou de pagar o empréstimo e, alguns anos depois, o banco processou a filha pedindo o restante do valor acrescido de juros, totalizando DM 160.000. Quando assinou o contrato de fiança, a filha não tinha formação profissional nem emprego em período integral e ganhava cerca de DM 1.150 por mês em uma fábrica de peixes. À época do processo, ela era uma mãe solteira que dependia da seguridade social (BVerfGE, $\S 14$ e 21).

Antes de o caso chegar à Corte Constitucional alemã, as instâncias inferiores haviam julgado que o contrato de fiança ou era contrário aos bons costumes, ou refletia uma violação da boa-fé por parte do banco quanto ao dever de informar sua contraparte na fase pré-contratual. 
O Superior Tribunal Federal (Bundesgerichtshof), por sua vez, sustentara que o resultado previsível do endividamento excessivo era razão insuficiente para tornar a fiança nula de pleno direito por contrariedade aos bons costumes. A Corte Constitucional alemã reverteu a decisão. Aduziu que, ao executar um tal contrato marcado por profundo desequilíbrio no poder de negociação e severas consequências para a parte mais fraca, os tribunais inferiores haviam negado a aplicação dos direitos constitucionais à dignidade humana e ao livre desenvolvimento da personalidade, combinados com o princípio do Estado social (BVerfGE, § 54). Na visão do tribunal, "há uma violação da garantia constitucional da autonomia privada quando o problema do poder de negociação desigual não é sequer tratado” pelos tribunais (BVerfGE, § 56).

A decisão Bürgschaft claramente acarretou interferência estatal - por meio de normas fundamentais do direito constitucional - na substância dos arranjos contratuais. À luz da assimetria existente no poder de negociação das partes, o tribunal tratou de adequar o contrato a valores e objetivos sociais mais amplos. Uma inspeção mais detida, contudo, revela que um elemento crítico no raciocínio decisório do tribunal foi o caráter aparentemente perpétuo ou insuperável da obrigação em tela - semelhante a uma "prisão por dívida" moderna - e as limitações que ela imporia às futuras escolhas de vida da devedora (CHEREDNYCHENKO, 2007, p. 226 e 308). A apelante enfatizou expressamente que ela nunca ganhou o suficiente sequer para pagar os juros do empréstimo; por isso, "não se pode considerar que a presente relação possa um dia vir a ser encerrada” (BVerfGE, § 21). Consequentemente, o raciocínio foi que "os tribunais devem negar reconhecimento a contratos que reduzem tão fortemente a liberdade de ação de uma das partes contratantes que a impossibilitem de viver com dignidade" (BVerfGE, § 20).

Essa limitação das escolhas de vida liga-se diretamente à ausência, na época, de mecanismos de exoneração contratual para os indivíduos no direito alemão de insolvência. Se os fatos desse caso tivessem ocorrido nos Estados Unidos, a filha fiadora provavelmente não teria tido dificuldade em obter um novo começo por meio de um pedido de insolvência. Isto é, o mesmo resultado - a reabilitação plena - seria alcançado, mas por um caminho diferente, baseado em normas claras que não exigem ingerência estatal relativamente ao mérito das cláusulas contratuais.

De fato, a intervenção estatal nas cláusulas contratuais e a fresh start na insolvência podem atuar como substitutos imperfeitos em uma ampla gama de situações (TRIANTIS, 1992, p. 482). Tomemos, por exemplo, o problema relativo à gestão de riscos exógenos, como doença ou desemprego, nas relações contratuais. Uma justificativa econômica usual, embora contestada, para um novo começo no direito da insolvência é que ele promove uma alocação eficiente desses riscos, transferindo-os à parte (nessa visão, o credor) que tem mais condições de suportá-los (HOWARD, 1987, p. 1047). Porém, mesmo concordando que essa alocação de risco é desejável do ponto de vista da eficiência ou da distribuição, a falência ou insolvência é somente um dos possíveis instrumentos para alcançar esse objetivo. Um sistema de direito romano-germânico pode obter o mesmo resultado por meio da aplicação do 
direito contratual - por exemplo, para permitir a revisão de cláusulas contratuais ou a extinção do contrato à luz da alteração superveniente das circunstâncias. A abordagem romano-germânica pode ser mais modulada aos riscos exógenos, mas também abre a porta para significativa discricionariedade judicial. ${ }^{10}$ Embora a aplicação da fresh start não dependa formalmente da presença de risco exógeno, expressiva parcela dos casos de insolvência reflete exatamente esse padrão (SULLIVAN et al., 2000).

É curioso que juristas progressistas na Europa continental denunciaram o aumento das hipóteses de reabilitação do falido, entre outros motivos, porque ela alija as reações jurídicas mais socialmente arraigadas, incorporadas no direito dos contratos. Em uma dura crítica à disseminação da fresh start na Europa, Udo Reifner afirmou que esse mecanismo pode efetivamente excluir o desenvolvimento de um "direito dos contratos mais socialmente adaptativo". Nas suas palavras,

o modelo de aprendizado reflexivo do direito dos contratos que, usando a boa-fé e os bons costumes, criou as leis de proteção dos trabalhadores, dos inquilinos e dos consumidores, bem como muitas outras medidas corretivas que garantem sua sobrevivência na sociedade industrializada, é gradualmente abandonado em procedimentos legais nos quais os juízes não se importam mais com as cláusulas dos contratos que fracassaram (REIFNER, 2003, p. 143 e 155).

Ao mesmo tempo, um "direito dos contratos socialmente cego leva a abordagens simples de insolvência” (REIFNER, 2003, p. 143 e 155). Portanto, segundo essa visão, a disseminação da reabilitação do falido na Europa pode ser tanto um produto da desregulação estatal quanto uma proteção contra novas intervenções do Estado nas cláusulas contratuais.

De modo geral, os regramentos jurídicos a respeito da substância e da exigibilidade das cláusulas contratuais podem atuar como substitutos em uma ampla gama de circunstâncias - embora os resultados finais não sejam necessariamente idênticos. Com efeito, sabe-se que cláusulas e remédios contratuais podem frequentemente servir como substitutos para se alcançar os mesmos fins (TRIANTIS, 2010, p. 646; TRIANTIS, 2000). Talvez por essa razão não haja um vencedor claro na chamada "concorrência regulatória no direito dos contratos": embora distintos em dimensões importantes, tanto o direito inglês quanto o direito suíço parecem ser as leis escolhidas com maior frequência, por partes empresariais sofisticadas, nos procedimentos de arbitragem internacional (VOIGT, 2008).

10 Em sentido contrário, Triantis (1992, p. 482) propugna que, ao distribuir os riscos entre todos os credores, uma política de novo começo pode promover objetivos de compartilhamento dos riscos de modo mais efetivo que o direito dos contratos, que apenas distribui o risco entre as partes contratantes. 


\section{CONCLUSÃo}

Este artigo procurou oferecer uma narrativa coerente de diferenças clássicas entre o direito dos contratos nas tradições romano-germânica e anglo-saxônica. Demonstrou-se que várias distinções dogmáticas partilham um padrão semelhante, no qual o Estado desempenha um papel mais forte no civil law e mais fraco no common law. Destacou-se que o grau de apoio comparativamente forte do Estado aos contratos privados no civil law desafia os estereótipos disseminados nesta matéria, mas se coaduna com as distinções mais amplas entre essas tradições jurídicas em outras áreas do direito.

Contudo, este é apenas um primeiro passo no esforço de revitalizar o estudo do direito comparado e da economia do direito dos contratos, uma área que é injustificadamente subdesenvolvida por três conjuntos de razões interrelacionadas. Primeiro, as obras dos comparatistas sobre o direito dos contratos continuam a sofrer do "mal-estar" renitente que assola o direito comparado como disciplina em geral, no qual a maioria das obras descrevem diferenças observadas, mas não as explica (VALCKE, 2009). Segundo, diferentemente de outras áreas de investigação comparativa, ainda há uma escassez de estudos que procuram entender a relação da natureza do direito e enforcement contratual, em um dado país, com outras estruturas políticas e econômicas. Finalmente, os economistas continuam a agir de acordo com a pressuposição não testada de que, enquanto as "instituições contratuais" têm importância profunda para o desenvolvimento econômico, o direito dos contratos em si seria irrelevante (PARGENDLER, 2017b). A ênfase em questões procedimentais de execução contratual não se traduziu em um interesse pela substância do que é executado, de modo que o direito dos contratos continua sendo uma "caixa-preta" (GOLDBERG, 2012, p. 270).

Porém, a priori não existe razão alguma para aceitar essa presumida irrelevância do direito dos contratos para a economia ou para a sociedade em geral (PARGENDLER, 2017b). Por certo, o direito dos contratos dos países desenvolvidos não é perfeito, como tampouco é ideal o regime de qualquer outra área do direito. Além disso, o fato de a análise econômica do direito dos contratos ser alegadamente indeterminada e infrutífera na previsão do conteúdo das regras jurídicas (POSNER, 2003) também sugere que existam outros fatores a moldar os institutos que conhecemos.

Esta análise vislumbrou além das tradicionais fronteiras disciplinares para alcançar também os institutos de direito da insolvência que têm impacto direto sobre a execução contratual. No entanto, é provável que as interdependências institucionais existentes relacionadas ao direito dos contratos sejam ainda maiores, abrangendo igualmente campos como as garantias reais, os direitos reais e até a extensão do welfare state (POSNER, 1995). A interdependência institucional pode levar à substituição funcional e, por isso, a diferenças práticas menores do que pareceriam à primeira vista. No entanto, os apelos para a convergência em uma única dimensão - por exemplo, no sentido de menos interferência do Estado nas cláusulas contratuais na civil law - podem levar a divergências ainda maiores na ausência de modificações complementares. 


\section{NOTA DE AGRADECIMENTO}

Este artigo enquadra-se em projeto "Direito dos negócios sob perspectiva comparada”, agraciado com Bolsa de Produtividade do CNPq no processo 303832/2015-0.

\section{REFERÊNCIAS}

ALBANESI, Stefania; NOSAL, Jaromir. Insolvency after the 2005 Bankruptcy Reform. Staff Report $n$. 725, 2015. Disponível em: <http://ssrn.com/abstract=2594037>. Acesso em: 10 out. 2017.

ARMOUR, John; ENRIQUES, Luca et al. The Anatomy of Corporate Law: A Comparative and Functional Approach. 3. ed. NewYork: Oxford University, 2017.

AYRES, Ian. Regulating Opt-Out: An Economic Theory of Altering Rules. Yale L. J., v. 121, p. 2032 $2116,2012$.

BAADE, Hans W. Comparative Law and the Practitioner. Am.J. Comp. L., v. 31, p. 499-510, 1983.

BAGCHI, Aditi. The Political Economy of Regulating Contract. Am.J. Comp. L., v. 62, p. 687-738, 2014.

BANCO MUNDIAL, Key Features of Common Law or Civil Law Systems (2015). Disponível em: $<$ http://ppp.worldbank.org/public-private-partnership/legislation-regulation/framework-assessment/legalsystems/common-vs-civil-law>. Acesso em: 10 out. 2017.

BEN-SHAHAR, Omri; POTTOW, John A. E. On the Stickiness of Default Rules. Fla. St. U. L. Rev., v. 33, p. 651-682, 2006.

BROOKS, Richard R.W.The Efficient Performance Hypothesis. Yale L.J., v. 116, p. 568-596, 2006.

CARDENAS, Jonathan. Deal Jumping in Cross-Border Merger \& Acquisition Negotiations: A Comparative Analysis of Pre-Contractual Liability under French, German, United Kingdom and United States Law. N.Y.U.J.L.\&Bus., v. 9, p. 941-975, 2013.

CHEREDNyCHENKO, Olha O. Fundamental Rights, Contract Law and the Protection of the Weaker Party. München: Sellier European Law, 2007. 
. The Constitutionalization of Contract Law: Something New Under the Sun?. Electronic J. Comp. L., v. 8, p. 1-6, 2004.

CLAESSENS, Stijn; KLAPPER, Leora F. Bankruptcy around the World: Explanations for Its Relative Use, Working Paper (2002). Disponível em: <http: / / documents. worldbank.org/curated/pt/311061468766468860/ Bankruptcy-around-the-world-explanations-of-its-relative-use >. Acesso em: 10 out. 2017.

COLOMBO, Sylviane. The Present Differences between the Civil Law and Common Law Worlds with Regard to Culpa in Contrahendo. Tilburg For. L. Rev., v. 2, p. 341-375, 1983.

DAMA ̌̌KA, Mirjan. The Faces of Justice and State Authority. New Haven:Yale University, 1986.

DANNEMANN, Gerhard. Common-law Based Contracts under German Law. In: CORDERO-MOSS, Giuditta (Ed.). Boilerplate Clauses, International Commercial Contracts and the Applicable Law. New York: Cambridge University, 2011.

DAVIS, Kevin E. The Role of Nonprofits in the Production of Boilerplate. Mich. L. Rev., v. 104, p. 1075 1103, 2006.

DAWSON, John P. Judicial Revision of Frustrated Contracts: The United States. B. U. L. Rev., v. 64, p. $1-38,1984$.

DIMATTEO, Larry A.; RICH, Bruce Louis. A Consent Theory of Unconscionability: An Empirical Study of Law in Action. F1. St. U. L. Rev., v. 33, p. 1067-1118, 2006.

EASTERBROOK, Frank H.; FISCHEL, Daniel R. Contract and Fiduciary Duty. J. L. \&Econ., v. 36, p. 425 446, 1993.

EBKE, Werner F.; STEINHAUER, Bettina M. The Doctrine of Good Faith in German Contract Law. In: BEATSON, Jack; FRIEDMANN, Daniel (Ed.). Good Faith and Fault in Contract Law. Oxford: Clarendon, 1995.

EDLIN, Aaron S.; HERMALIN, Benjamin E. Contract Renegotiation and Options in Agency Problems. J. L. Econ. \&Org., v. 16, p. 395-423, 2000.

EDLIN, Aaron S.; SCHWARTZ, Alan. Optimal Penalties in Contracts. Chi-Kent L. Rev., v. 78, p. 33-54, 2003.

EISENBERG, Melvin A. Actual and Virtual Specific Performance, the Theory of Efficient Breach, and the Indifference Principle in Contract Law. Cal. L.Rev., v. 93, n. 4, p. 975-1050, 2005. 
EISENBERG, Theodore; MILLER, Geoffrey P. Damages Versus Specific Performance: Lessons from Commercial Contracts. J. Emp. L. Stud., v. 12, p. 29-69, 2015.

EÖRSI, Gyula. Contractual Remedies in Socialist Legal Systems. International Encyclopedia of Comparative Law, v. 16, 1987.

FARNSWORTH, Allan Edward. A Common Lawyer's View of His Civilian Colleagues. La. L. Rev., v. 57, p. 227-238, 1996.

Comparative Contract Law. In: REIMANN, Mathias; FARNSWORTH, Allan Edward (Ed.). Contracts. 3. ed. Boston: Kluwer, 1999.

. Precontractual Liability and Preliminary Agreements: Fair Dealing and Failed Negotiations. Colum. L.Rev., v. 87, t. 2, p. 217-294, 1987.

FLEMING. The Rise and Fall of Unconscionability as the 'Law of the Poor'. Geo. L. J., v. 102, p. 1383 $1441,2014$.

FRIEDMANN, Daniel. The Efficient Breach Fallacy. J. Legal Stud., v. 18, n. 1, p. 1-24, 1989.

GINSBURG,Tom; DIXON, Rosalind (Ed.). Comparative Constitutional Law. Cheltenham: Edward Elgar, 2013.

GOETZ, Charles J.; SCOTT, Robert E. Liquidated Damages, Penalties and the Just Compensation Principle: Some Notes on an Enforcement Model and a Theory of Efficient Breach. Colum. L. Rev., v. 77, p. 554-594, 1977.

GOLDBERG, Victor. Contracts. In: MUELLER, Dennis C. (Ed.). The Oxford handbook of capitalism. New York: Oxford University, 2012.

GOTANDA, John Y. Damages in Lieu of Performance because of Breach of Contract. Villanova Law / Public Policy Research Paper n. 2006-8. Disponível em: <http://papers.ssrn.com/sol3/papers.cfm? abstract_id=917424>. Acesso em: 10 out. 2017.

GROSSFELD, Bernhard. Money Sanctions for Breach of Contract in a Communist Economy. Yale L. J., v. 72 , p. $1326-1346,1963$.

GROSSMAN, Andrew. Conflict of Laws in the Discharge of Debts in Bankruptcy. Int'l Insolvency Rev. v. 5, n. 1, p. 1-35, 1996. 
HALPERN, Sheldon W. Application of the Doctrine of Commercial Impracticability: Searching for the "Wisdom of Solomon”. U.Pa.L.Rev., v. 135, n. 5, p. 1123-1178, 1987.

HATZIS, Aristides N. Having the Cake and Eating It Too: Efficient Penalty Clauses in Common and Civil Contract Law, Int. Rev. L. \&Econ., v. 22, p. 381-406, 2003.

HAYEK, Friedrich August. Law, Legislation and Liberty: A New Statement of the Liberal Principles of Justice and Political Economy. Chicago: University of Chicago, 1973.

HOLMES, Oliver Wendell. The Path of the Law. Harv. L. Rev., v. 10, p. 457-478, 1897.

HOWARD, Margaret. A Theory of Discharge in Consumer Bankruptcy. Ohio St. L. J., v. 48, p. 10471088, 1987.

HULS, Nick. American Influences on European Consumer Bankruptcy Law. J. Consum. Pol'y, v. 15, n. 2, p. 125-142, 1992.

. A Next Step in Debt Enforcement: The Merger of Debt Help and Debt Collection. J. Consum. Policy, v. 35, p. 497-508, 2012.

KAHAN, Marcel; KLAUSNER, Michael. Path Dependence in Corporate Contracting: Increasing Returns, Herd Behavior and Cognitive Biases. Wash. U. L. Q., v. 74, p. 347-366, 1996.

. Standardization and Innovation in Corporate Contracting (or the 'Economics of Boilerplate'). Va.L.Rev., v. 83, p. 713-770, 1997.

KESSLER, Friedrich; FINE, Edith. Culpa in Contrahendo, Bargaining in Good Faith, and Freedom of Contract: A Comparative Study. Harv. L. Rev., v. 77, p. 401-449, 1964.

KILBORN, Jason J. The Innovative German Approach to Consumer Debt Relief: Revolutionary Changes in German Law, and Surprising Lessons for the United States. Nw. J. Int'l L. \& Bus., v. 24, p. 257-297, 2003-2004.

KLASS, Gregory. Contract Law in USA. Boston: Kluwer, 2010.

KOROBKIN, Russell. Inertia and Preference in Contract Negotiation: The Psychological Power of Default Rules and Form Terms. Vand.L.Rev., v. 51, p. 1583-1651, 1998a.

.The Status Quo Bias and Contract Default Rules. Cornell L. Rev., v. 83, p. 608-687, 1998b. 
KÖTZ, Hein. Contract Law in Europe and the United States: Legal Unification in the Civil Law and Common Law. Tu1. Eur. \& Civ. L.F., v. 27, p. 1-16, 2012.

.The Jurisdiction of Choice: England and Wales or Germany?. Eur. Rev. Priv. L., v. 18, t. 6, p. 1243 1257, 2010.

LANDO, Henrik; ROSE, Caspar. On the Enforcement of Specific Performance in Civil Law Countries. Int'l Rev. L. \&Econ., v. 24, t. 4, p. 473-487, 2004.

LA PORTA, Rafael; LOPEZ-DE-SILANES, Florencio; SHLEIFER, Andrei. The Economic Consequences of Legal Origins. J. Econ. Lit., v. 46, p. 285-332, 2008.

LAWLESS, Robert M.; WARREN, Elizabeth. Shrinking the Safety Net: The 2005 Changes in U.S. Bankruptcy Law. Illinois Law and Economics Working Papers Series, Research Paper n. LE06-031 (2006). Disponível em: <http://ssrn.com/abstract=949629>. Acesso em: 10 out. 2017.

LAW SOCIETY OF ENGLAND AND WALES. England and Wales:The Jurisdiction of Choice. London: The Law Society of England and Wales, 2007. Disponível em: <http://www.eversheds.com/documents/ LawSocietyEnglandAndWalesJurisdictionOfChoice.pdf>. Acesso em: 10 out. 2017.

LAYCOCK, Douglas. The Death of the Irreparable Injury Rule. New York: Oxford University, 1991.

LEGRAND, Pierre. European Legal Systems Are not Converging. Int’l \& Comp. L.Q, v. 45, p. 52-81, 1996.

LEONHARD, Chunlin. Beyond the Four Corners of a Written Contract: A Global Challenge to U.S. Contract Law. Pace Int'l L. Rev., v. 21, p. 1-36, 2009.

LONDON ECONOMICS. Study on Means to Protect Consumers in Financial Difficulty: Personal Bankruptcy, Datio in Solutum of Mortgages, and Restrictions on Debt Collection Abusive Practices (Contract No. MARKT/2011/023/B2/ST/FC 2012). Disponível em: <https://londoneconomics.co.uk/blog/ publication/ study-on-means-to-protect-consumers-in-financial-difficulty-personal-bankruptcy-datio-insolutum-of-mortgages-and-restrictions-on-debt-collection-abusive-practices/> . Acesso em: 10 out. 2017.

LOPES, José Reinaldo de Lima. Consumer Bankruptcy and Over-indebtedness in Brazil. In: NIMEI-KIESILÄINEN, Johanna; RAMSAY, Iain; WHITFORD, William C. (Org.). Consumer Bankruptcy in Global Perspective. Oxford, Portland (Oregon): Hart, 2003, v. 1.

MACAULAY, Stewart. An EmpiricalView of Contract. Wis. L. Rev., p. 465-483, 1985. 
MACKAAY, Ejan. Good Faith in Civil Law Systems. Cirano Scientific Series 2011s-74 (2011). Disponível em: <http://ssrn.com/abstract=1998924>. Acesso em: 10 out. 2017.

MACNEIL, Ian R. Power of Contract and Agreed Remedies. Cornell L. Q., v. 47, p. 495-521, 1961.

MAGNUS, Ulrich. The Germanic Tradition: Application of Boilerplate Clauses under German Law. In: CORDERO-MOSS, Giuditta (Ed.). Boilerplate Clauses, International Commercial Contracts and the Applicable Law. New York: Cambridge University, 2011.

MARTINS-COSTA, Judith. A boa-fé no direito privado: critérios para a sua aplicação. São Paulo: Marcial Pons, 2015.

MATTEI, Ugo. The Comparative Law and Economics of Penalty Clauses in Contracts. Am.J. Comp. L, v. 43, n. 3, p. 427-444, 1995.

MILHAUPT, Curtis; PISTOR, Katharina. Law and Capitalism. Chicago: University of Chicago, 2008.

NICHOLAS, Barry. Rules andTerms: Civil Law and Common Law. Tul.L. Rev., v. 48, p. 946-972, 1973.

NIEMI-KIESILÄINEN, Johanna. Consumer Bankruptcy Comparison: Do We Cure a Market Failure or a Social Problem?. Osgoode Hall L.J., v. 37, p. 473-503, 1999.

PARGENDLER, Mariana. Modes of Gap Filing: Good Faith and Fiduciary Duties Reconsidered. Tul. L. Rev., v. 82, p. 1315-1354, 2007.

Desenho Contratual em Perspectiva Comparada: Reflexões sobre a Relação entre Tipificação Legal e Inovação Contratual. Revista da Faculdade de Direito da UFPR, v. 61, p. 219-245, 2016.

. The Role of the State in Contract Law: The Common-Civil Law Divide. Yale J. Int'1. L., v. 43, 2017a (no prelo).

Comparative Contract Law and Development:The Missing Link? Geo.Wash.L.Rev., v. 85, 2017b (no prelo).

PISTOR, Katharina. Legal Ground Rules in Coordinated and Liberal Market Economies. In: HOPT, Klaus J. et al. (Ed.). Corporate Governance in Context: Corporations, States, and Markets in Europe, Japan, and the U.S. New York: Oxford University, 2005.

POSNER, Eric A. Contract Law in the Welfare State: A Defense of the Unconscionability Doctrine, 
Usury Laws, and Related Limitations on the Freedom to Contract. J. Legal Stud., v. 24, p. 283-319, 1995.

Economic Analysis of Contract Law after Three Decades: Success or Failure? Yale L.J., v. 112, p. 829-880, 2003.

POSNER, Richard. Economic Analysis of Law. Boston: Little Brown, 1973.

Economic Analysis of Law. 2. ed. Boston: Little Brown, 1977.

RAMSAY, Iain. Comparative Consumer Bankruptcy. U. Ill. L. Rev., p. 241-273, 2007.

REIFNER, Udo et al. Consumer Overindebtedness and Consumer Law in the European Union. Contract Reference $\mathrm{n}$. B5-1000/02/000353. Final Report presented by the: Institute For Financial Services e.V., Erasmus University Rotterdam/School of Law, University of Helsinki/Helsinki Collegium for Advanced Studies to the: Commission of the European Communities, Health and Consumer Protection Directorate-General. 2003. Disponível em: <http://www.knl.lv/raksti_data/1147/parskats_ES_2003.pdf>.Acesso em: 10 out. 2017.

REIFNER, Udo. “Thou Shalt Pay Thy Debts”: Personal Bankruptcy Law and Inclusive Contract Law. In: NIEMI-KIESILÄINEN, Johanna; RAMSAY, Iain (Ed.). Consumer Bankruptcy in Global Perspective. Portland: Hart, 2003.

REITZ, John C. Political Economy and Contract Law. In: SCHULZE, Reiner (Ed.). New Features in Contract Law. München: Sellier European Law, 2007.

SCALISE JR., Ronald J. Why No "Efficient Breach" in the Civil Law?: A Comparative Assessment of the Doctrine of Efficient Breach of Contract. Am.J. Comp. L., v. 55, p. 721-766, 2007.

SCHLESINGER, Rudolf B. et al. Comparative Law: Cases, Text, Materials. 6. ed. NewYork: Foundation, 1988.

SCHWARTZ, Alan. Optimal Penalties in Contracts. Chi-Kent L. Rev., v. 78, p. 33-54, 2003.

SHAVELL, Steven. Is Breach of Contract Immoral?. Emory L.J., v. 56, p. 439-460, 2006.

SHIFFRIN, Seana. Could Breach of Contract Be Immoral?. Mich. L. Rev., v. 107, p. 1551-1566, 2009.

SKEEL, David. Debt's Dominion:A History of Bankruptcy Law in America. Princeton: Princeton University, 2014.

. Vern Countryman and the Path of Progressive (and Populist) Bankruptcy Scholarship. Harv. L. Rev., v. 113, p. 1075-1129, 2000. 
SMITS, Jan M.; CALOMME, Caroline. The Reform of the French Law of Obligations: Les Jeux Sont Faits, Maastricht European Private Law Institute Working Paper No. 2016/05 (2016). Disponível em: $<$ https: / / ssrn.com/abstract $=2845796>$. Acesso em: 10 out. 2017.

SPAMANN, Holger. Contemporary Legal Transplants: Legal Families and the Diffusion of (Corporate) Law. B.Y.U.L.Rev., p. 1813-1878, 2009.

SULLIVAN, Teresa A.; WARREN, Elizabeth; WESTBROOK, Jay Lawrence. As We Forgive Our Debtors: Bankruptcy and Consumer Credit in America. New York: Oxford University, 1989.

. The Fragile Middle Class:Americans in Debt. New Haven:Yale University, 2000.

TABB, Charles J. Lessons from the Globalization of Consumer Bankruptcy. L. \& Soc. Inq., p. 763 $782,2005$.

TEUBNER, Gunther. Legal Irritants: Good Faith in British Law or How Unifying Law Ends Up in New Divergences. Modern L.Rev, v. 61, p. 11-32, 1998.

TREITEL, Guenter H. Remedies for Breach of Contract (Courses of Action Open to a Party Aggrieved). In:VON MEHREN, Arthur (Ed.). International Encyclopedia of Comparative Law, v. 7, 1976.

TRIANTIS, George G. Contractual Allocations of Unknown Risks: A Critique of the Doctrine of Commercial Impracticability. U.Toronto L.J., v. 42, n. 4, p. 450-483, 1992.

The Evolution of Contract Remedies (And Why Do Contracts Professors Teach Remedies First?). U.Toronto L.J., v. 60, p. 643-662, 2010.

. Unforeseen Contingencies. Risk Allocation in Contracts. In: BOUCKAERT, Boudewijn; GEEST, Gerrit de (Ed.). Encyclopedia of Law and Economics, v. 3, 2000.

TUSHNET, Mark. The Issue of State Action/Horizontal Effect in Comparative Constitutional Law. Int.J. Const.L., v. 1, n. 1, p. 79-98, 2003.

ULEN, Thomas S. The Efficiency of Specific Performance: Toward a Unified Theory of Contract Remedies. Mich.L.Rev., v. 83, p. 341-403, 1984.

VALCKE, Chatherine. On Comparing French and English Contract Law: Insights from Social Contract Theory. Am.J. Comp.L., v. 4, p. 69-95, 2009. 
VOGENAUER, Stefan. Interpretation of Contracts: Concluding Comparative Observations. In: BURROWS, Andrew; PEEL, Edwin (Ed.). Contract Terms. NewYork: Oxford University, 2007.

VOIGT, Stefan. Are International Merchants Stupid? Their Choice of Law Sheds Doubt on the Legal Origin Theory. J. Emp. L. Stud., p. 1-20, 2008.

VON MEHREN, Arthur (Ed.). International Encyclopedia of Comparative Law, v. 7, 1976.

WHITE, Michelle J. Bankruptcy Law. In: POLINSKY, A. Mitchell; SHAVELL, Steven (Ed.). Handbook of Law and Economics. London: Elsevier, 2006.

Why It Pays to File for Bankruptcy: A Critical Look at the Incentives under U.S. Personal Bankruptcy Law and a Proposal for Change. U. Chi.L.Rev., v. 65, n. 3, p. 685-732, 1998.

WHITMAN, James Q. The Two Western Cultures of Privacy: Dignity Versus Liberty. Yale L.J., v. 113, p. 1151-1221, 2004.

ZIEGEL, Jacob. Facts on the Ground and Reconciliation of Divergent Consumer Insolvency Philosophies. Theoretical Inq. L., v. 7, p. 299-321, 2006.

ZIMMERMANN, Reinhard; WHITTAKER, Simon (Ed.). Good faith in European Contract Law. New York: Cambridge University, 2000.

ZIMMERMANN, Reinhard (Ed.). Oxford Handbook of Comparative Law. New York: Oxford University, 2006.

ZWEIGERT, Konrad; KÖTZ, Hein. An Introduction to Comparative Law, 3. ed. Oxford: Clarendon, 1998.

Mariana Pargendler

Professora da Escola de Direito de São Paulo da Fundação Getulio Vargas (FGV Direito SP) e Global Professor of LAW dA NEW York University SchOOL OF LAW.

mariana.pargendlerafgv.br 